\title{
The Effect of In Vivo Hydrocortisone on Subpopulations of Human Lymphocytes
}

\author{
Anthony S. Fauci and David C. Dale \\ From the Laboratory of Clinical Investigation, National Institute of Allergy \\ and Infectious Diseases, National Institutes of Health, \\ Bethesda, Maryland 20014
}

A B S T R A C T This study was designed to determine the effect of in vivo hydrocortisone on subpopulations of lymphoid cells in normal humans. Subjects received a single intravenous dose of either $100 \mathrm{mg}$ or $400 \mathrm{mg}$ of hydrocortisone, and blood was drawn at hourly intervals for $6 \mathrm{~h}$, and then again at 10 and $24 \mathrm{~h}$ after injection. Profound decreases in absolute numbers of circulating lymphocytes and monocytes occurred at $4-6 \mathrm{~h}$ after both $100 \mathrm{mg}$ and $400 \mathrm{mg}$ of hydrocortisone. Counts returned to normal by $24 \mathrm{~h}$. The relative proportion of circulating thymus-derived lymphocytes as measured by the sheep red blood cell rosette assay decreased maximally by $4 \mathrm{~h}$ and returned to base line by $24 \mathrm{~h}$ after hydrocortisone. There was a selective depletion of functional subpopulations of lymphocytes as represented by differential effects on in vitro stimulation with various mitogens and antigens. Phytohaemagglutinin response was relatively unaffected, while responses to concanavalin A were significantly diminished. Responses to pokeweed mitogen were unaffected by $100 \mathrm{mg}$ of hydrocortisone, but greatly diminished by $400 \mathrm{mg}$ of hydrocortisone. In vitro responses to the antigens streptokinase-streptodornase and tetanus toxoid were markedly diminished by in vivo hydrocortisone. Reconstitution of monocyte-depleted cultures with autologous monocytes partially corrected the diminished response to antigens. This transient selective depletion of monocytes and subsets of human lymphocytes by a single dose of hydrocortisone is most compatible with a redistribution of these cells out of the circulation into other body compartments.

\section{INTRODUCTION}

Corticosteroids are widely used in clinical medicine as chemotherapeutic agents in the treatment of a diversity

Presented in part at the National Meeting of the American Federation for Clinical Research, 29 April 1973, Atlantic City, N. J.

Received for publication 14 June 1973 and in revised form 10 August 1973. of diseases, especially those in which inflammatory or immunological phenomena are believed to play a predominant role (1). Despite this, little is known about the precise mechanisms of action of corticosteroids on the immune response in humans $(1,2)$. Several immunosuppressive effects of these agents have been observed to occur in man, including mild lymphocytopenia (3), decreased immunoglobulin production (4), and impaired expression of cutaneous delayed hypersensitivity responses (5). The striking heterogeneity of lymphoid cell populations within different species including man has been the subject of recent intense study (6). In some animal species, corticosteroids have been shown to have differential effects on subpopulations of lymphocytes $(7,8)$.

In man, different mitogens have been shown to differentially stimulate particular subpopulations of lymphocytes in vitro (9). Stimulation of thymus-derived lymphocytes by antigens in vitro is felt to require the interaction of macrophage and lymphocyte (10). The responsiveness of lymphocytes when cultured in vitro with various mitogens and antigens is generally agreed to reflect in vivo immunological function (11). Hence, in order to study the effects of in vivo hydrocortisone $(\mathrm{OHC})^{x}$ administration upon cellular immune responses in humans, normal volunteers were given intravenous $\mathrm{OHC}$ and the following parameters were measured: absolute numbers of circulating lymphocytes and monocytes, relative proportions of subpopulations of circulating lymphocytes, and the function of these subpopulations as determined by in vitro stimulation with various mitogens and antigens.

${ }^{1}$ Abbreviations used in this paper: $\mathrm{B}$ lymphocytes, bone marrow-derived lymphocytes; Con A, concanavalin A; HBSS, Hanks balanced salt solution; MEM-S, Eagle's minimum essential media modified for suspension culture; OHC, hydrocortisone; PHA, phytohemagglutinin; PWM, pokeweed mitogen; SK-SD, streptokinase-streptodornase; SRBC, sheep red blood cells; TCA, trichloroacetic acid; $\mathrm{T}$ lymphocytes, thymus-derived lymphocytes; TT, tetanus toxoid; WBC, white blood cell. 


\section{METHODS}

Subjects. 10 normal adult volunteers of either sex, ages $20-27 \mathrm{yr}$ each received a single dose of $100 \mathrm{mg}$ and 400 $\mathrm{mg}$ of hydrocortisone sodium succinate (The Upjohn Co., Kalamazoo, Mich.) intravenously on separate occasions at least 1 wk apart. None of the subjects were taking any medications during the study period. The injections of $\mathrm{OHC}$ were given at $8 \mathrm{a} . \mathrm{m}$., and subjects were required to remain in their rooms at minimal activity during the test period. Venous blood was obtained immediately before $\mathrm{OHC}$ injection $(0 \mathrm{~h})$, at hourly intervals for the first $6 \mathrm{~h}$, and again at 10 and $24 \mathrm{~h}$ after administration. White blood cell $(\mathrm{WBC})$ and differential counts, plasma cortisol levels, and Hypaque-Ficoll mononuclear cell separations were performed on the blood samples. Six other normal adult volunteers of similar sex and age range as the above subjects were used as normal controls. They underwent the same protocol studies except that they received $4 \mathrm{ml}$ of normal saline intravenously instead of $\mathrm{OHC}$.

Total leukocyte and differential counts. WBC counts were performed using a Coulter Counter (model Fn, Coulter Electronics, Inc., Hialeah, Fla.), and differential counts were performed on peripheral blood smears stained with Wright's stain. 200 cells were counted per smear by the same observer throughout the study.

Plasma cortisol levels. $10 \mathrm{ml}$ of venous blood was obtained in a syringe moistened with heparin (Eli Lilly \& Co., Indianapolis, Ind., 1,000 USP units per $\mathrm{ml}$ ) at 0 , 1, 4 , and $24 \mathrm{~h}$ for determination of plasma cortisol levels. The determinations were kindly performed by Drs. M. B. Lipsett and L. D. Loriaux using a radioimmunoassay (12).

Preparation and culture of mononuclear cells. Mononuclear cells (lymphocytes and monocytes) were obtained by hypaque-ficoll separation (13) of heparinized venous blood obtained at $0,1,4$, and $24 \mathrm{~h}$. The mononuclear cells were washed three times in Eagle's minimum essential media modified for suspension culture (MEM-S) (Grand Island Biological Co., Grand Island, N. Y.). For culture, MEM-S was supplemented with $0.02 \mathrm{M}$ L-glutamine, penicillin $100 \mathrm{U} / \mathrm{ml}$, streptomycin sulfate $100 \mu \mathrm{g} / \mathrm{ml}$ (National Institutes of Health Media Supply Section), and $15 \%$ homologous $\mathrm{AB}$ serum (Antibodies, Inc., Washington, D. C.) in $5 \% \mathrm{CO}_{2}$. Triplicate cultures containing $2 \mathrm{ml}$ of cells were incubated in air, at $100 \%$ humidity. The concentrations were adjusted so that each culture contained $0.5 \times 10^{\circ}$ lymphocytes per $\mathrm{ml}$. The lymphocyte to monocyte ratio was consistently between 8 and 9 to 1 in the $0 \mathrm{~h}$ samples and between 20 and 30 to 1 in the 4-h samples. Mitogens or antigens were added to the cultures in previously determined optimal stimulatory doses. The mitogens used were: phytohemagglutinin (PHA) MR 68, lot K4402 (Wellcome Reagents Ltd., Beckenham, England), optimal dose $1 \mu \mathrm{g} / \mathrm{ml}$ of culture; concanavalin A (Con A), lot 2145 (Nutritional Biochemicals Corp., Cleveland, Ohio), optimal dose $10 \mu \mathrm{g} / \mathrm{ml}$ of culture; pokeweed mitogen (PWM), lot 180690 (Grand Island Biological Co., Grand Island, N. Y.), optimal dose $0.1 \mathrm{ml}$ of $1: 10$ dilution in distilled water per $2 \mathrm{ml}$ of culture. The antigens used were: streptokinasestreptodornase (SK-SD), lot 5-2201-66 (Lederle Laboratories Div., American Cyanamid Co., Pearl River, N. Y.), optimal dose $25 \mathrm{U}$ streptokinase, $6.75 \mathrm{U}$ streptodornase per $\mathrm{ml}$ of culture; tetanus toxoid (TT), lot L 01246 (Eli Lilly and Co., Indianapolis, Ind.), optimal dose 1.5 flocculation units per $\mathrm{ml}$ of culture. Cultures containing mitogens were incubated for 3 days and those containing antigens were incubated for 5 days. $4 \mathrm{~h}$ before harvesting, $2 \mu \mathrm{Ci}$ of tritiated thymidine $(6.7 \mathrm{Ci} / \mathrm{mM}$, New England Nuclear, Boston, Mass.) were added to each culture tube. The cells were collected on Millipore filters using a 3025 Millipore sampling manifold (Millipore Corp., Bedford, Mass.). The filters were then washed with $10 \%$ trichloroacetic acid (TCA) and $95 \%$ ethanol (14), and placed in $10 \mathrm{ml}$ of Aquasol (New England Nuclear). The TCA-precipitable activity was then counted in a liquid scintillation counter model LS-250 (Beckman Instruments, Inc., Fullerton, Calif.). The arithmetic mean of triplicate cultures was determined and the degree of stimulation was expressed as the difference in counts per minute per $10^{\circ}$ lymphocytes between stimulated and unstimulated (control) cultures $(\triangle \mathrm{CPM})$.

Reconstitution of monocyte-depleted lymphocyte cultures. In order to determine to what extent, if any, depletion of circulating monocytes by hydrocortisone administration is responsible for decreased in vitro lymphocyte response to antigens, reconstitution experiments were performed. Six separate normal volunteers received $400 \mathrm{mg}$ of $\mathrm{OHC}$ intravenously. As described above, Hypaque-Ficoll-separated mononuclear cells from $0 \mathrm{~h}$ and $4 \mathrm{~h}$ after $\mathrm{OHC}$ were cultured in the presence of SK-SD and TT. In addition, an aliquot of mononuclear cells from the pretreatment $(0 \mathrm{~h})$ sample was set aside and irradiated with $2000 \mathrm{R}$ from a cobalt-60 gamma source (Gammator M, Kewaunee Scientific Equipment, Adrian, Mich.). This procedure renders lymphocytes unable to divide while mononuclear phagocytic cells can still function normally (15). This irradiated sample from $0 \mathrm{~h}$ was then added to cultures of post-OHC (4 h) cells in a concentration such that the number of monocytes added would equal the standard number of monocytes in the original $0 \mathrm{~h}$ culture. In this way, the 4-h cultures would have at least the same numbers of normal monocytes as the $0 \mathrm{~h}$ cultures. In order to control for any nonspecific effect of irradiated autologous lymphocytes on cultures, aliquots of 4-h cells (which are monocyte-depleted) were also irradiated and added back to standard 4-h cultures. Thus, we can determine the in vitro response to SK-SD and TT of cells before OHC administration, $4 \mathrm{~h}$ after $\mathrm{OHC}, 4 \mathrm{~h}$ after $\mathrm{OHC}$ plus monocyte-rich irradiated cells, and $4 \mathrm{~h}$ after $\mathrm{OHC}$ plus monocyte-depleted irradiated cells.

Proportion of circulating thymus-derived lymphocytes. The percentage of circulating lymphocytes which formed rosettes with sheep red blood cells (SRBC) was determined (16). In this assay thymus-derived ( $T$ ) lymphocytes, but nat bone marrow-derived (B) lymphocytes, bind SRBC to form rosettes. To $0.25 \mathrm{ml}$ of the lymphocyte suspension $\left(4 \times 10^{\circ}\right.$ cells $\left./ \mathrm{ml}\right)$ in Hanks balanced salt solution (HBSS) (National Institutes of Health Media Supply Section) was added $0.25 \mathrm{ml}$ of $0.5 \%$ SRBC. The mixed cell suspension was incubated at $37^{\circ} \mathrm{C}$ for $5 \mathrm{~min}$ and centrifuged at $200 \mathrm{~g}$ for $5 \mathrm{~min}$ at $4^{\circ} \mathrm{C}$, and the supernatant HBSS was then removed. $0.5 \mathrm{ml}$ of fetal calf serum (Gray Industries, Inc., Fort Lauderdale, Fla.) which had been absorbed twice with SRBC was then added and the pellet was incubated at $4^{\circ} \mathrm{C}$ overnight. One-half the volume of supernate was then removed and the cells were gently resuspended by shaking. One drop of cell suspension was put on a glass slide and a cover slip was applied. 200 lymphocytes were counted by the same observer throughout the study using phase contrast optics at $400 \times$ magnification on a Zeiss microscope (Carl Zeiss, Oberkochen, West Germany). All lymphocytes binding more than three SRBC were considered positive. The total number of $T$ cells per $\mathrm{mm}^{\mathbf{3}}$ for 


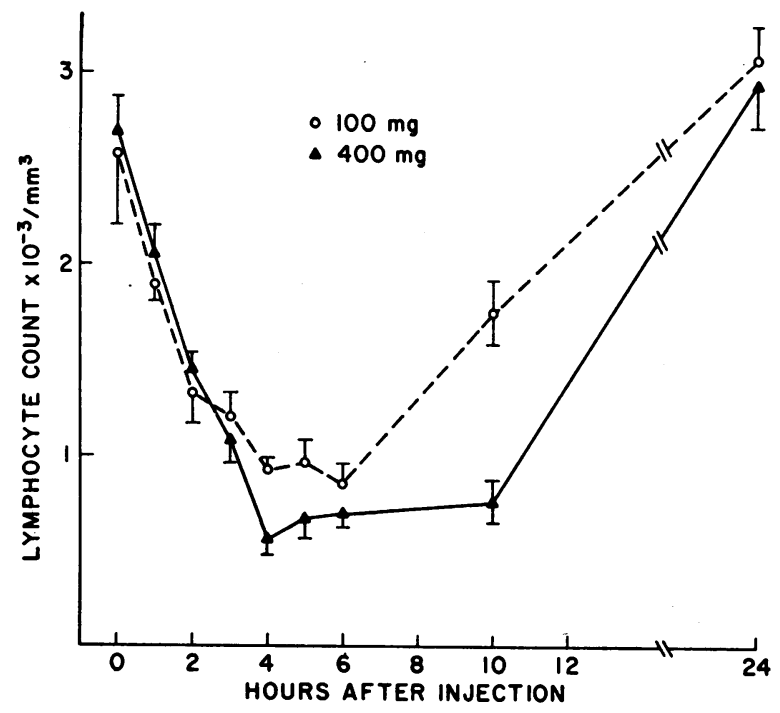

Frgure 1 Absolute circulating lymphocyte counts after $\mathrm{OHC}$ administration. Mean levels ( \pm SEM) for the various time intervals after injection of $\mathrm{OHC}$ are shown.

each individual was determined by multiplying the percent rosettes by the total lymphocyte count.

In order to rule out the possibility that corticosteroid binding to lymphocytes might interfere with SRBC rosette formation, a series of control experiments were performed. Hypaque-Ficoll-separated lymphocytes were collected from 10 normal adult laboratory personnel (six males, four females, ages 25-32 yr.), one person per day for 10 separate days. The rosette assay was carried out exactly as described above except that the lymphocytes were first incubated for $\frac{1}{2} \mathrm{~h}$ at $37^{\circ} \mathrm{C}$ with varying concentrations $(100 \mu \mathrm{g} / \mathrm{ml}, 10$ $\mu \mathrm{g} / \mathrm{ml}, 1 \mu \mathrm{g} / \mathrm{ml}$, and $0.1 \mu \mathrm{g} / \mathrm{ml}$ ) of $\mathrm{OHC}$ and then washed three times with HBSS before mixing with SRBC.

Analysis of results. The total circulating lymphocyte and monocyte counts as well as the percent rosettes and total rosettes per $\mathrm{mm}^{3}$ are expressed as the arithmetic mean with the standard error (SE) for the subjects at each time interval after OHC. For the stimulation with mitogens and antigens the results are expressed as the percent change in stimulation comparing 1,4 , and $24 \mathrm{~h}$ after $\mathrm{OHC}$ injection with $0 \mathrm{~h}$ (immediately before injection). The geometric mean of percent changes at each time interval for the experimental and control groups were compared applying Students' $t$ test to the corresponding mean $\log$ values (17). The $70 \%$ confidence interval around each mean was derived by taking antilogs of the mean $\log \pm \mathrm{SE}$ (18).

\section{RESULTS}

Plasma cortisol levels. Markedly elevated plasma cortisol levels of $131( \pm 54)$ and $250( \pm 60) \mu \mathrm{g} / 100 \mathrm{ml}$ at $1 \mathrm{~h}$ and $32( \pm 4.3)$ and $137( \pm 37) \mu \mathrm{g} / 100 \mathrm{ml}$ at $4 \mathrm{~h}$ after injection of $100 \mathrm{mg}$ and $400 \mathrm{mg}$ of OHC, respectively, were observed. By $24 \mathrm{~h}$ plasma cortisol levels had returned to base line in both groups.

Lymphocyte and monocyte counts. The effects of $\mathrm{OHC}$ on absolute circulating lymphocyte and monocyte counts are shown in Figs. 1 and 2. With both $100 \mathrm{mg}$ and
$400 \mathrm{mg}$ of $\mathrm{OHC}$, the lymphocyte counts show a sharp decrease reaching their lowest levels at 4-6 h after OHC, with a subsequent gradual increase so that by $24 \mathrm{~h}$ the counts have returned to base line. The curves for both doses of $\mathrm{OHC}$ are quite similar except for a slight lag in return to base line with $400 \mathrm{mg} \mathrm{OHC}$ as seen at the $10 \mathrm{~h}$ level.

The monocyte counts likewise fall abruptly reaching lowest levels at 4-6 h after $\mathrm{OHC}$ with a similar lag in return to base line seen with the $400 \mathrm{mg}$ dose. At the 4-6-h levels, the monocyte counts approach zero, only to return to base line by $24 \mathrm{~h}$.

$T$ cell rosettes. The percent and absolute number per $\mathrm{mm}^{3}$ of rosette-forming $\mathrm{T}$ lymphocytes decreased maximally after both $100 \mathrm{mg}(P<0.02)$ and $400 \mathrm{mg}(P<$ 0.01 ) of OHC (Table I). As with the absolute lymphocyte and monocyte counts, there was a return to base line by $24 \mathrm{~h}$.

In vitro incubation of lymphocytes with $\mathrm{OHC}$ had no effect on the ability of these cells to form rosettes with SRBC. In the 10 separate subjects whose lymphocytes were incubated in HBSS as well as varying concentrations of $\mathrm{OHC}$, there was no difference in the percent rosettes formed. In HBSS the mean percent of rosettes was $52.3( \pm 3.5)$. When incubated with even the highest concentration of OHC $(100 \mu \mathrm{g} / \mathrm{ml})$, the mean percent was $55.2( \pm 2.8)$.

Response of cultured lymphocytes to mitogens and antigens. Table II lists the percent changes in lymphocyte stimulation with the different mitogens and antigens at various time intervals after $\mathrm{OHC}$ injection. The most dramatic reductions in stimulation are seen at $1 \mathrm{~h}$ and

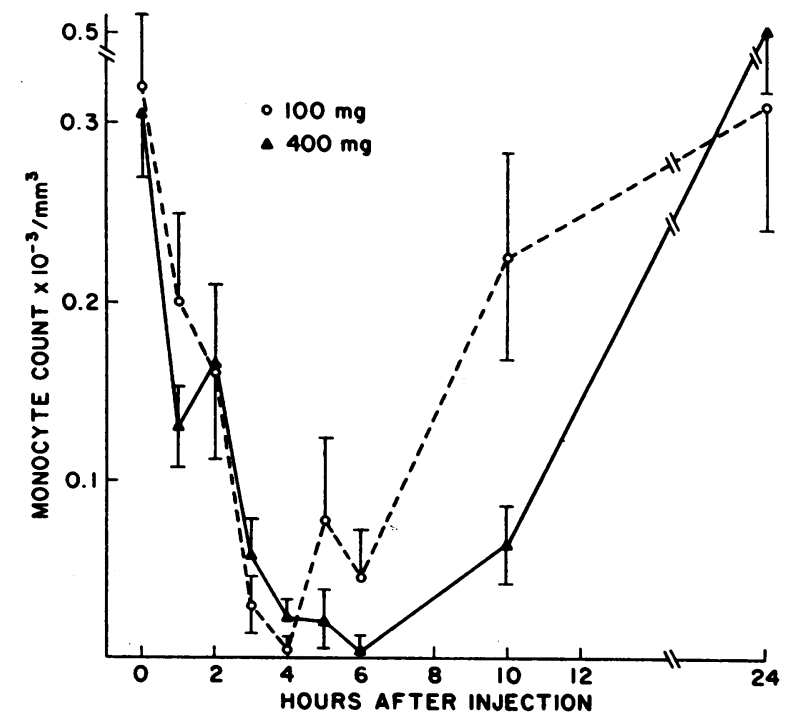

FIGURE 2 Absolute circulating monocyte counts after OHC administration. Mean levels $( \pm \mathrm{SEM})$ for the various time intervals after injection of $\mathrm{OHC}$ are shown. 
TABLE I

Effect of Hydrocortisone on Circulating T Lymphocytes

\begin{tabular}{|c|c|c|c|c|}
\hline \multirow[b]{2}{*}{ Time after OHC } & \multicolumn{2}{|c|}{ Percent rosettes } & \multicolumn{2}{|c|}{ Total rosettes (no. $\left./ \mathrm{mm}^{3}\right)$} \\
\hline & $100 \mathrm{mg}$ & $400 \mathrm{mg}$ & $100 \mathrm{mg}$ & $400 \mathrm{mg}$ \\
\hline$h$ & & & & \\
\hline 0 & $48.5( \pm 3.5)^{*}$ & $49.8( \pm 4.2)$ & $1252( \pm 191)$ & $1325( \pm 129)$ \\
\hline 1 & $45.5( \pm 5.8)$ & $35.8( \pm 5.4)$ & $875( \pm 126)$ & $726( \pm 122)$ \\
\hline 4 & $32.7( \pm 4.6)$ & $30.9( \pm 4.1)$ & $301( \pm 41)$ & $174( \pm 33)$ \\
\hline 24 & $40.0( \pm 4.5)$ & $52.3( \pm 2.9)$ & $1189( \pm 186)$ & $1411( \pm 108)$ \\
\hline
\end{tabular}

* Mean $( \pm \mathrm{SE})$ for 10 subjects.

$4 \mathrm{~h}$ after injection of $400 \mathrm{mg}$ of $\mathrm{OHC}$. A comparison of the differential effects of $\mathrm{OHC}$ on the in vitro lymphocyte responses to each stimulus at these time intervals and $\mathrm{OHC}$ dose is illustrated in Fig. 3.

At $1 \mathrm{~h}$ with $100 \mathrm{mg} \mathrm{OHC}$ (Table II) there is no significant change from base line with any of the mitogens and antigens tested. At $4 \mathrm{~h}$ with $100 \mathrm{mg} \mathrm{OHC}$ the response to $\mathrm{PWM}$ is essentially unchanged $(+4 \%)$, the response to $\mathrm{PHA}$ is not significantly decreased $(-21 \%$, $P>0.10$ ), while the response to Con A is markedly. decreased $(-59 \%, P<0.05)$. The response to SK-SD is not significantly decreased $(-26 \%, P>0.2)$, while the response to TT is markedly decreased $(-45 \%, P<$ 0.02 ) at this dose of $\mathrm{OHC}$.

With $400 \mathrm{mg}$ OHC several responses are reduced with a definite differential pattern (Fig. 3). At 1 and 4 h, the response to PHA is not significantly changed. The response to Con $A$ is reduced slightly at $1 \mathrm{~h}$, but still not significantly, while at $4 \mathrm{~h}$ the response to Con $A$ is markedly decreased $(-56 \%, P<0.01)$ in sharp contrast to the response to $\mathrm{PHA}$ at $4 \mathrm{~h}$. With $400 \mathrm{mg} \mathrm{OHC}$, the response to $P W M$ is not significantly changed at 1 h. At $4 \mathrm{~h}$ it is greatly decreased $(-46 \%, P<0.05)$ in contrast to its resistance to $100 \mathrm{mg} \mathrm{OHC}$ at $4 \mathrm{~h}$ (Table II). The responses to the antigens SK-SD and TT are highly sensitive to the effects of $400 \mathrm{mg}$ of OHC both at $1 \mathrm{~h}$ and $4 \mathrm{~h}$ after injection (Fig. 3). The data given are those for optimal stimulatory concentrations of mitogens and antigens. In several experiments various concentrations of mitogens and antigens both greater and less than optimum were also tested. Similar differential sensitivities seen at optimal doses were also observed at these doses.

Reconstitution of monocyte-depleted lymphocyte cultures. The effects of adding monocyte-rich cells to monocyte-depleted cultures are shown in Table III. As in the previous experiments, $4 \mathrm{~h}$ after $\mathrm{OHC}$ administration there is a marked decrease in in vitro response to antigens SK-SD and TT. Adding irradiated, monocyterich cells from $0 \mathrm{~h}$ samples to monocyte-depleted 4-h cultures results in a partial, but not a complete reconstitution of the responses which is not seen when irradiated monocyte-depleted cells are added to the 4-h cultures $(P<0.02$, paired sample $t$ test $)$. The lack of any

TABLE II

Effect of In Vivo Hydrocortisone on Lymphocyte Transformation

\begin{tabular}{|c|c|c|c|}
\hline & $1 \mathrm{~h}$ & $4 \mathrm{~h}$ & $24 \mathrm{~h}$ \\
\hline \multicolumn{4}{|c|}{ Percent change in stimulation after $100 \mathrm{mg} \mathrm{OHC}^{*}$} \\
\hline PHA & $+5(-15$ to +29$)$ & $-21(-36$ to -3$)$ & $0(-30$ to +41$)$ \\
\hline Con A & $-18(-34$ to +3$)$ & $-59(-71$ to -42$)$ & $+11(-9$ to +37$)$ \\
\hline PWM & $+3(-15$ to +24$)$ & $+4(-5$ to +14$)$ & $+15(-4$ to +39$)$ \\
\hline SK-SD & $+13(-8$ to +39$)$ & $-26(-50$ to +10$)$ & $+8(-11$ to +30$)$ \\
\hline TT & $-8(-12$ to -4$)$ & $-45(-59$ to -25$)$ & $+3(-18$ to +29$)$ \\
\hline \multicolumn{4}{|c|}{ Percent change in stimulation after $400 \mathrm{mg} \mathrm{OHC}$} \\
\hline PHA & $-8(-17$ to +1$)$ & $-17(-26$ to -6$)$ & $-11(-21$ to \\
\hline Con A & $-20(-29$ to -10$)$ & $-56(-63$ to -48$)$ & $+2(-20$ to +30$)$ \\
\hline PWM & $-16(-22$ to -9$)$ & $-46(-57$ to -33$)$ & $+2(-16$ to +26$)$ \\
\hline SK-SD & $-32(-37$ to -25$)$ & $-60(-73$ to -39$)$ & $0(-21$ to +26$)$ \\
\hline TT & $-23(-28$ to -16$)$ & $-66(-71$ to -60$)$ & $+16(+3$ to +31$)$ \\
\hline
\end{tabular}

* Data given as geometric means of the percent changes in the groups studied; numbers in parentheses are $70 \%$ confidence intervals (18). 
TABLE III

Effect of Monocyte Reconstitution on In Vitro Lymphocyte Response to Antigens After OHC Adminstration

\begin{tabular}{ccccccccc}
\hline Subject & \multicolumn{2}{c}{ 0 h culture } & \multicolumn{2}{c}{ 4 h culture } & \multicolumn{2}{c}{$\begin{array}{c}\text { 4 h culture plus } \\
\text { monocyte-rich cells }\end{array}$} & \multicolumn{2}{c}{$\begin{array}{c}\text { 4 h culture plus } \\
\text { monocyte-depleted cells }\end{array}$} \\
\hline & SK-SD & TT & SK-SD & TT & SK-SD & TT & SK-SD & TT \\
B. B. & $27,493^{*}$ & 42,685 & 8,578 & 15,915 & 15,682 & 30,795 & 8,043 & 19,485 \\
M. H. & 103,845 & 53,766 & 73,908 & 21,338 & 89,270 & 20,868 & 62,275 & 21,250 \\
C. C. & 77,498 & 66,361 & 20,715 & 18,538 & 67,988 & 39,760 & 25,790 & 25,845 \\
S. R. & 54,226 & 74,929 & 25,325 & 16,160 & 35,485 & 26,630 & 24,650 & 19,668 \\
P. P. & 98,436 & 71,413 & 58,594 & 31,367 & 63,528 & 36,308 & 45,135 & 27,743 \\
K. D. & 50,368 & 13,656 & 13,013 & 1,405 & 20,705 & 5,353 & 13,333 & 1,443 \\
Mean $( \pm$ SE) & 68,644 & 53,802 & 33,356 & 17,454 & 48,776 & 26,619 & 29,871 & 19,239 \\
& $( \pm 12,166)$ & $( \pm 9,398)$ & $( \pm 10,853)$ & $( \pm 3,964)$ & $( \pm 11,953)$ & $( \pm 5,064)$ & $( \pm 8,320)$ & $( \pm 3,816)$ \\
\hline
\end{tabular}

${ }^{*} \mathrm{cpm} / 10^{5}$ lymphocytes in stimulated cultures minus $\mathrm{cpm} / 10^{6}$ lymphocytes in unstimulated cultures $(\Delta \mathrm{cpm})$.

effect of adding irradiated, monocyte-depleted cells to the $4 \mathrm{~h}$ culture also serves as a control demonstrating that adding irradiated autologous lymphocytes to standard cultures does not have a nonspecific adjuvant or suppressant effect on the response to antigens.

\section{DISCUSSION}

It has been firmly established that in man there exist heterogeneous subpopulations of lymphocytes. Two broad categories, bone marrow-derived and thymus-derived cells, can be identified by surface markers $(16,19)$. Functionally, these broad categories, as well as various

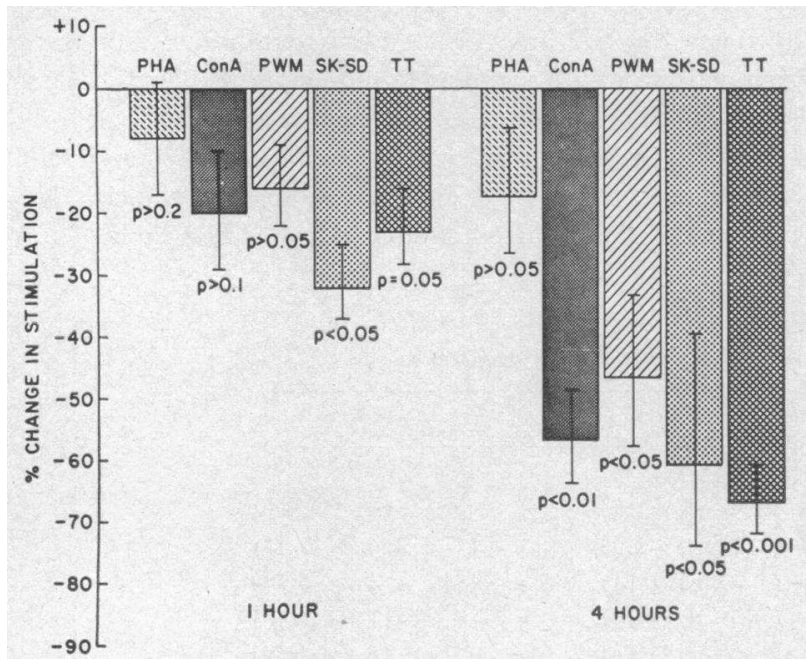

FIGURE 3 Differential effects of $400 \mathrm{mg}$ of in vivo OHC on the in vitro lymphocyte response to various mitogens (PHA, Con A, PWM) and antigens (SK-SD, TT). Data shown are the geometric mean values together with $1 \mathrm{SE}$ of the percent changes in lymphocyte stimulation at $1 \mathrm{~h}$ and $4 \mathrm{~h}$ after $\mathrm{OHC}$ administration. The $P$ values represent the significance of these changes in response using a 2 sample $t$ test comparing the subjects who received OHC with six controls who did not receive OHC but had similar lymphocyte studies done. subsets are defined by their differential in vitro responsiveness to various mitogens (9). In addition, optimal in vitro responsiveness to antigenic stimuli requires the interaction of a critical proportion of phagocytic cells with the responding lymphocytes (10).

The present studies demonstrate that a single intravenous dose of $\mathrm{OHC}$ has a profound effect upon circulating lymphoid cells that is both rapid in onset and transient in duration. The absolute numbers of circulating lymphocytes and monocytes are decreased, with a definite pattern of decline and recovery after both a 100 and 400 mg dose of OHC (Figs. 1 and 2).

Of interest is the fact that the depletion of lymphocytes from the circulation is selective, in that there is a proportionately greater decrease in the number of $\mathrm{T}$ cells as measured by the SRBC rosette assay. This observation could indicate either a true selective depletion of circulating rosette forming $\mathrm{T}$ cells, or alternatively, an interference with the ability of these cells to form rosettes. The finding that high concentrations of $\mathrm{OHC}$ added to the rosette assay does not interfere with the ability of $T$ cells to form rosettes is evidence against the latter point and strengthens the argument that there is a true selective removal of $T$ cells from the circulation with $\mathrm{OHC}$ administration.

The heterogeneity of lymphocytes in lower animals has been well-defined, both by surface markers $(20,21)$ and functional properties (22-24). Corticosteroids have been shown to have a distinctly differential effect upon these subpopulations in that they cause selective depletion of cells from tissues $(7,25)$ and changes in their circulation patterns $(8,26)$ and in their functional capacities as determined by in vitro stimulation $(27,28)$. In addition, the interaction of antigen sensitive lymphocyte and nonimmune macrophage is affected by corticosteroids $(29,30)$.

In humans, it is possible to fractionate lymphocytes into functionally distinct subpopulations by glass wool 
column separation (9). Recently, two subpopulations of lymphocytes were separated by passage through a nylon column (31). The subpopulations were distinguished by their differential responsiveness to in vitro stimulation by Con $\mathrm{A}$. The column-adherent lymphocytes were highly responsive to Con $\mathrm{A}$, while the nonadherent lymphocytes were relatively unresponsive to Con A. Both columnfiltered and unfiltered cells responded nearly equally to both PHA and PWM. This mechanical depletion of a functional subpopulation of lymphocytes described above is analogous to the pharmacological depletion of subpopulations of lymphocytes by $\mathrm{OHC}$ administration demonstrated in the present study. That $\mathrm{OHC}$ removes lymphocytes from the circulation is clear from the profound decrease in absolute lymphocyte counts (Fig. 1). The cells which remained in the circulation after OHC administration were no different in response to $\mathrm{PHA}$ than circulating cells before $\mathrm{OHC}$ administration. In contrast, cells remaining in the circulation after $\mathrm{OHC}$ administration were markedly depleted of Con A-responsive lymphocytes as compared to circulating cells before $\mathrm{OHC}$ administration (Table II). The response to PWM was unchanged after $100 \mathrm{mg} \mathrm{OHC}$, yet markedly diminished after $400 \mathrm{mg} \mathrm{OHC}$. Hence, administration of $\mathrm{OHC}$ not only causes an absolute lymphopenia, but selectively depletes certain functional subpopulations of lymphocytes (Con A- and PWM-responsive cells).

The relative proportions of subpopulations of lymphocytes have been studied in several diseases $(32,33)$. In this regard, evidence presented here that corticosteroid administration can selectively deplete rosette-forming $T$ cells as well as certain functional subpopulations of lymphocytes has potential clinical significance. As knowledge accumulates of the precise role of identifiable subpopulations of lymphocytes in the pathogenesis of certain immunologically mediated diseases, familiarity with the differential sensitivities of these subpopulations to corticosteroids will allow for greater therapeutic specificity in the use of these agents.

The effect of $\mathrm{OHC}$ administration on the in vitro response to antigens is quite dramatic (Fig. 3). This diminution of in vitro antigen responsiveness after $\mathrm{OHC}$ correlates well with the suppression of cutaneous delayed hypersensitivity to antigens during corticosteroid administration (5). The finding of differentially greater $\mathrm{OHC}$ sensitivity of in vitro antigen stimulation of lymphocytes as compared to PHA stimulation (Fig. 3) is in accord with others (34) who found that a group of renal transplantation patients who were receiving prednisone had suppression of lymphocyte stimulation by Candida antigen without significant inhibition of PHA response.

The mechanisms of this selectively greater depression by corticosteroids of antigen response is unclear. Mono- cytes play a critical role in the in vitro response to antigens (10), and monocytes are established components of the cutaneous delayed hypersensitivity reaction (35). The dramatic fall in absolute monocyte counts at 4-6 h after $\mathrm{OHC}$ (Fig. 2) may be the crucial factor in the reduction of antigen responsiveness. The addition of irradiated, autologous monocyte-rich cell suspensions to the cultures of cells depleted of monocytes by $\mathrm{OHC}$ administration results in a partial, but not a complete reconstitution of response to antigens (Table III). This is in accord with studies (10) in which cell suspensions depleted of monocytes by glass bead column treatment had diminished in vitro responses to antigens. The deficient response was likewise partially corrected by the addition of autologous monocyte-rich cell suspensions. Hence, monocyte depletion caused by $\mathrm{OHC}$ administration clearly is responsible at least in part for the decreased in vitro response to antigenic stimulation seen in the present study. In addition, deficiency of one or more of the functional lymphocyte subpopulations which were shown to be selectively depleted may also contribute to the decreased in vitro response to antigens.

The precise mechanisms whereby the absolute lymphocyte counts decline rapidly and return to base line within $24 \mathrm{~h}$ are unclear. The mechanism for this decrease in cell numbers could be explained either by direct destruction or redistribution of lymphocytes out of the circulation to other body compartments. In man, there is no convincing evidence that corticosteroids even in pharmacologic doses cause significant destruction of normal lymphocytes in vivo (2). In addition, corticosteroids added in vitro to human peripheral blood lymphocyte (36) and thymocyte (37) suspensions in concentrations far exceeding attainable in vivo pharmacological levels had no cytolytic effects. It seems highly likely, therefore, that the dramatic depletion of circulating monocytes and subpopulations of lymphocytes following $\mathrm{OHC}$ administration is due to a redistribution of cells out of the circulation into other body compartments as has been described in certain animals $(8,26,38)$. Experiments tracing the fate of labeled lymphocytes and monocytes after corticosteroid administration may clarify this hypothesis.

\section{ACKNOWLEDGMENTS}

The authors thank Ms. Kathy A. O'Meara, Ms. Sandra Crosby, and Mr. Stanley B. Ward for expert technical assistance.

\section{REFERENCES}

1. Schwartz, R, S. 1968. Immunosuppressive drug therapy. In Human Transplantation. F. T. Rapaport and J. Dausset, editors. Grune and Stratton, New York. 440.

2. Claman, H. N. 1972. Corticosteroids and lymphoid cells. N. Engl. J. Med. $287: 388$.

3. Coburg, A. J., S. H. Gray, F. H. Katz, I. Penn, C. Halgrimson, and T. E. Starzl. 1970. Disappearance 
rates and immunosuppression of intermittent intravenously administered prednisolone in rabbits and human beings. Surg. Gynecol. Obst. 131: 933.

4. Butler, W. T., and R. D. Rossen. 1973. Effect of methylprednisolone on immunoglobulin metabolism in man. Fed. Proc. 32: 1028.

5. Bovornkitti, S., P. Kangsadal, P. Sathirapat, and P. Oonsombatti. 1960. Reversion and reconversion rate of tuberculin skin reactions in correlation with the use of prednisone. Dis. Chest. 38 : 51 .

6. Craddock, C. G., R. Longmire, and R. McMillan. 1971. Lymphocytes and the immune response. N. Engl. J. Med. $285: 324,378$.

7. Esteban, J. N. 1968. The differential effect of hydrocortisone on the short-lived small lymphocyte. Anat Rec. $162: 349$.

8. Cohen, J. J. 1972. Thymus-derived lymphocyte sequestered in the bone marrow of hydrocortisone-treated mice. J. Immunol. 108: 841 .

9. Douglas, S. D., R. M. Kamin, and H. H. Fudenberg. 1969. Human lymphocyte response to phytomitogens in vitro: normal, agammaglobulinemic and paraproteinemic individuals. J. Immunol. $103: 1185$.

10. Oppenheim, J. J., B. G. Leventhal, and E. M. Hersh. 1968. The transformation of column-purified lymphocytes with nonspecific and specific antigenic stimuli. $J$. Immunol. $101: 262$.

11. Bloom, B. R. 1971. In vitro approaches to the mechanism of cell-mediated immune reactions. Adv. Immunol. 13: 101 .

12. Loriaux, D. L., R. Guy, and M. B. Lipsett. 1973 A simple, quick, solid-phase method for radioimmunoassay of plasma estradiol in late pregnancy and of plasma cortisol. J. Clin. Endocrinol. Metabol. 36: 788.

13. Böyum, A. 1968. Isolation of mononuclear. cells and granulocytes from human blood. Scand. J. Clin. Lab. Invest. $21: 77$.

14. Robbins, J. H., P. G. Burk, and W. R. Levis. 1969. A rapid and specific assay of DNA synthesis in lymphocyte cultures. Fed. Proc. 28: 363.

15. Schechter, G. P., and W. McFarland. 1970. Interaction of lymphocytes and a radioresistant cell in PPD-stimulated human leukocyte cultures. J. Immunol. 105: 661.

16. Jondal, M., G. Holm, and H. Wigzell. 1972. Surface markers on human $T$ and $B$ lymphocytes. I. A large population of lymphocytes forming nonimmune rosettes with sheep red blood cells. J. Exp. Med. 136: 207.

17. Dixon, W. J., and F. J. Massey, Jr. 1957. Introduction to Statistical Analysis. McGraw-Hill Book Company, New York. 2nd edition. 116.

18. Wilks, S. S. 1962. Mathematical Statistics. J. Wiley \& Sons, Inc., New York. 1st edition. 366.

19. Grey, H. M., E. Rabellino, and B. Pirofsky. 1971. Immunoglobulins on the surface of lymphocytes. IV. Distribution in hypogammaglobulinemia, cellular immune deficiency, and chronic lymphatic leukemia. J. Clin. Invest. $50: 2368$

20. Unanue, E. R., M. Grey, E. Rabellino, P. Campbell, and J. Schmidtke. 1971. Immunoglobulins on the surface of lymphocytes. II. The hone marrow as the main source of lymphocytes with detectable surface-bound immunoglobulins. J. Exp. Med. 133 : 1188.

21. Bianco, C., and V. Nussenzweig. 1971. Theta-bearing and complement receptor lymphocytes are distinct populations of cells. Science (Wash. D. C.). 173: 154.
22. Stobo, J. D., A. S. Rosenthal, and W. E. Paul. 1972. Functional heterogeneity of murine lymphoid cells. I. Responsiveness to and surface binding of concanavalin $\mathrm{A}$ and phytohemagglutinin. J. Immunol. 108: 1 .

23. Cantor, H., and R. J. Asofsky. 1972. Synergy among lymphoid cells mediating the graft-versus-host response. III. Evidence for interaction between two types of thymus derived cells. J. Exp. Med. 135: 764.

24. Shortman, K., W. J. Byrd, J. C. Cerottini, and K. T. Brunner. 1973. Characterization and separation of mouse lymphocyte subpopulations responding to phytohemagglutinin and pokeweed mitogens. Cell. Immunol. $6: 25$.

25. Quittner, H., N. Wald, L. N. Sussman, and W. Antopol. 1951. The effect of massive doses of cortisone on the peripheral blood and bone marrow of the mouse. Blood. 6: 513.

26. Moorhead, J. W., and H. N. Claman. 1972. Thymusderived lymphocytes and hydrocortisone: identification of subsets of theta-bearing cells and redistribution to bone marrow. Cell. Immunol. $5: 74$.

27. Levine, M. A., and H. N. Claman. 1970. Bone marrow and spleen: dissociation of immunologic properties of cortisone. Science (Wash., D. C.). 167: 1515.

28. Vischer, T. L. 1972. Effect of hydrocortisone on the reactivity of thymus and spleen cells of mice to in vitro stimulation. Immunology. 23: 777.

29. Weston, W. L., H. N. Claman, and G. G. Krueger. 1973. Site of action of cortisol in cellular immunity. J. Immunol. 110 : 880.

30. Balow, J. E., and A. S. Rosenthal. 1973. Glucocorticoid suppression of macrophage migration inhibitory factor. J. Exp. Med. 137: 1031 .

31. Boldt, D., A. M. Skinner, and S. Kornfeld. 1972. Studies of two subpopulations of human lymphocytes differing in responsiveness to concanavalin A. J. Clin. Invest. 51: 3225.

32. Wybran, J., and H. H. Fudenberg. 1973. Thymus-derived rosette-forming cells in various human disease states: cancer, lymphoma, bacterial and viral infections, and other diseases. J. Clin. Invest. 52: 1026.

33. Farid, N. R., R. E. Munro, V. V. Row, and R. Volpé. 1973. Peripheral thymus-dependent (T) lymphocytes in Graves's disease and Hashimoto's thyroiditis. N. Engl. J. Med. 288: 1313.

34. Folb, P. I., and J. R. Trounce. 1971. Selective pharmacological inhibition of lymphocyte stimulation. Lancet. 2: 221.

35. Mackaness, G. B. 1970. The monocyte in delayed-type hypersensitivity. In Mononuclear Phagocytes. R. Van Furth, editor. Blackwell Scientific Publications, Oxford. 1st edition. 1: 478.

36. Caron, G. A. 1969. The effect of antimetabolites and corticosteroids on lymphocyte transformation in vitro. In Proceedings of the Third Annual Leucocyte Culture Conference. W. O. Rieke, editor. Appleton-CenturyCrofts, New York. 287.

37. Claman, H. N., J. W. Moorhead, and W. H. Benner. 1971. Corticosteroids and lymphoid cells in vitro. I. Hydrocortisone lysis of human, guinea pig, and mouse thymus cells. J. Clin. Lab. Med. 78: 499.

38. Thompson, J., and R. Van Furth. 1973. The effect of glucocorticosteroids on the proliferation and kinetics of promonocytes and monocytes of the bone marrow. J. Exp. Med. 137: 10. 